\title{
Optimization of Methane Gas Formation Rate with The Addition of EM4 Starter-made from Tofu Liquid Waste and Husk Rice Waste Using Biogas Reactor-Fixed Dome in Langensari West Ungaran
}

\author{
Fahmi Arifan ${ }^{1}$, Fuad Muhammad ${ }^{2}$, Sri Winarni ${ }^{3}$, Hafizh Rama Devara ${ }^{1}$, Latifah Hanum ${ }^{1}$ \\ ${ }^{1}$ Departmen of Chemical Engineering, Faculty of Engineering, Diponegoro University \\ ${ }^{2}$ Departmen of Biology, Faculty of Science and Mathematics, Diponegoro University \\ ${ }^{3}$ Department of Biostatistic and Population study, Public Health, Diponegoro University
}

\begin{abstract}
Indonesia is a country that has abundant energy resources, namely oil, gas, coal, geothermal, and so forth. Biogas is an alternative fuel that can be used as a substitute for primary fuel. The term biogas is already familiar to the people, it is because biogas has usefulness as a vehicle fuel, domestic (cooking), and generate electricity. Cow dung has a value of $\mathrm{C} / \mathrm{N}$ ratio is large enough that 18 . Rice husk has a $\mathrm{C} / \mathrm{N}$ ratio is sufficient High temperatures of 38.9. EM-4 (effective microorganism) is a bacterial culture which is usually used as an activator. In the manufacture of biogas from waste fluids out and chaff has the advantage because the content of the $\mathrm{C} / \mathrm{N}$ is high enough. The composition of the raw materials used are liquid wastes out of $5 \mathrm{~kg}$ and $1 \mathrm{~kg}$ of husk-em with the addition of $4500 \mathrm{ml}$ and the resulting calorific value of 1047.9 A fermentation time for 9 days. Ph maintained in neutral or alkaline conditions, namely 7-7.5, because the effectiveness of the methane formation is highly dependent on $\mathrm{pH}$ wherein the microorganism will grow and thrive in neutral. The test results has been done is the color of the flame and the time at yield is good enough where the color of the flame produced at day to 9 blue with time for 40 seconds.
\end{abstract}

\section{Introduction}

Based on data from the Directorate General of Oil and Gas that shows the fuel oil consumption last 5 years start from 2006-2010, as many as 211345 tons with an average increase of 42269 per year and for gas consumption by 93,282 tons with an average increase of 18656 tonnes per year and at 2014 is projected to reach 167906 tonnes of fuel gas consumption in Indonesia [1]. With the increasing need for fuel for the population in Indonesia is not possible sometime in the future energy reserves exist in nature will be exhausted in view of an increased need for fuel oil and gas is a matter that can not be avoided and will continue to occur due to the increased population of the total population and the emergence of new industries and technologies that will continue to grow [2]. On the other hand, that the oil and gas reserves are owned by Indonesia increasingly limited because it is a product that can not be renewed. Therefore it is necessary for efforts to seek alternative fuels and environmentally friendly. Biogas is an alternative fuel that can be used as a substitute for primary fuel. The term biogas is already familiar to the people, it is because biogas has usefulness as a vehicle fuel, domestic (cooking), and generates electric power [3]. Biogas in the process usually requires considerable time to produce methane gas which is about 60-90 days.
The main content of the biogas is methane and carbon dioxide. One of the things that affect the production of $\mathrm{CH} 4$ in biogas is the relationship between the amount of carbon (C) and nitrogen $(\mathrm{N})$ contained in the organic material is expressed in terms of the ratio of $\mathrm{C}-\mathrm{N}$ and $\mathrm{PH}$ also greatly affects the growth rate of biogas [4]. Waste know has a value of $\mathrm{C} / \mathrm{N}$ ratio is large enough that 18 . Rice husk has a C / $\mathrm{N}$ ratio is sufficient High temperatures of 38.9. With the $\mathrm{C} / \mathrm{N}$ ratio is high is owned by rice husk waste out and expected to get quite a lot of methane gas from the second material is that by mixing the two. EM-4(effective microorganism) is a bacterial culture which is usually used as an activator. EM-4 may be added to a mixture of both ingredients so as to accelerate the formation of methane in Biogas Reactor Type Fixed Dome.

\section{Method}

Biogas production with waste materials out of the waste material consists out of $5 \mathrm{~kg}$ and EM-4500 ml. Biogas production process consists of two phases: preliminary and mixing the ingredients. To control the results obtained to be checked $\mathrm{pH} 3$ days once within 17 days. Analysis of the results is done by connecting a gas stove on a biodigester through the tank.

Corresponding author: fahmiarifan80@gmail.com 
Table 1. Observations

\begin{tabular}{ccccccccccc}
\hline $\begin{array}{c}\text { Days } \\
\text { to- }\end{array}$ & $\begin{array}{c}\text { Teactor } \\
\text { Rea } \\
\left({ }^{\circ} \mathbf{C}\right)\end{array}$ & $\begin{array}{c}\text { Increase } \\
\text { in Gas } \\
\text { Level }(\mathbf{c m})\end{array}$ & $\begin{array}{c}\text { Gas } \\
\text { volume } \\
\left(\mathbf{c m}^{3}\right)\end{array}$ & pH & $\begin{array}{c}\text { Time } \\
\text { light test } \\
(\mathbf{s e c o n d})\end{array}$ & Light Colour & $\begin{array}{c}\mathbf{T}_{\mathbf{1}} \\
\left({ }^{\mathbf{O}} \mathbf{C}\right)\end{array}$ & $\begin{array}{c}\mathbf{T}_{2} \\
\left({ }^{\circ} \mathbf{C}\right)\end{array}$ & $\begin{array}{c}\Delta \mathbf{T} \\
\left({ }^{\circ} \mathbf{C}\right)\end{array}$ & $\begin{array}{c}\text { Calor } \\
(\mathbf{J})\end{array}$ \\
\hline 1 & 25 & 0 & - & 7,5 & & & - & - & - & - \\
2 & 25 & 0 & - & 7,5 & & & - & - & - & - \\
3 & 25 & 0 & - & 7 & & & - & - & - & - \\
4 & 25 & 0 & - & 6,5 & & & - & - & - & - \\
5 & 25 & 0 & - & 6,5 & & & - & - & - & - \\
6 & 26 & 0 & - & 6 & & & - & - & - & - \\
7 & 26 & 0 & - & 6 & & & - & - & - & - \\
8 & 26 & 0 & - & 5,5 & & & - & - & - & - \\
9 & 26 & 0,5 & 830,53 & 5,5 & 2 & Orange Yellow & 30 & 30 & 0 & - \\
& & & & & & & & & & - \\
10 & 27 & 1 & 1661,06 & 5,5 & 2 & Orange Yellow & 30 & 30 & 0 & - \\
11 & 27 & 1 & 1661,06 & 6 & 10 & Blue Yellow & 30 & 30 & 0 & - \\
12 & 27 & 1,5 & 2491,59 & 6,5 & 17 & Blue Yellow & 30 & 30,5 & 0,5 & 209,58 \\
13 & 27 & 1,8 & 2989,908 & 6,5 & 23 & Blue Yellow & 30 & 30,5 & 0,5 & 209,58 \\
14 & 27 & 2,2 & 3654,332 & 6,5 & 29 & Blue & 30 & 31 & 1 & 419,16 \\
15 & 27 & 3 & 4983,18 & 6,5 & 34 & Blue & 30 & 31,5 & 1,5 & 628,74 \\
16 & 27 & 3,3 & 5481,498 & 7 & 37 & Blue & 30 & 32 & 2 & 838,32 \\
17 & 27 & 3,9 & 6478,134 & 7 & 40 & Blue & 30 & 32,5 & 2,5 & 1047,9 \\
\hline
\end{tabular}

Trial of making biogas from waste out coupled with bacterial Effective Microorganism (EM). These bacteria function as decomposers and shorten the adaptation phase or phase lag of the safety. Make sure the connection is completely secure. Heats $250 \mathrm{ml}$ of water and made observations flame colors produced.

\section{Results and Discussion}

Manufacture of biogas from waste out with the addition of EM-4 processed in batches, to determine the biogas production capacity and caloric value. Parameters measured were level at the height of the reactor biogas, biogas formed by the test flame test and the magnitude of the heat produced by the biogas in heating $100 \mathrm{ml}$ of water. Data retrieval is done during the 17-day observation process of degradation. [5]

In experiments that have been carried out, the increase in the level of the gas cylinder holder be the first indicator of the formation of gas. The result of gas formation is one sign that the addition of bacterial inoculum (EM) as a bio-activator started working decipher the ingredients. Nutrients needed by microbes derived from raw materials, without any additional supply of nutrients from the outside in the form of the addition of urea or TSP. The purpose is not to the addition of these nutrients is to determine the length of microbes to degrade the waste out there in the feed biogas. $[4,6]$.

Observation of the formation of gas volume is done every day starting from the first reactor to operate up to 17 days. The increase in water level in the gas holder showed large volume of gas produced each day.

From the results it is observed that on the ninth day with $\mathrm{Ph} 6$ has seen an increase in water level as high as $0.5 \mathrm{~cm}$. Having tested using the flame turns the flame color indicated yellowish orange. It can be seen that the gas is not methane.

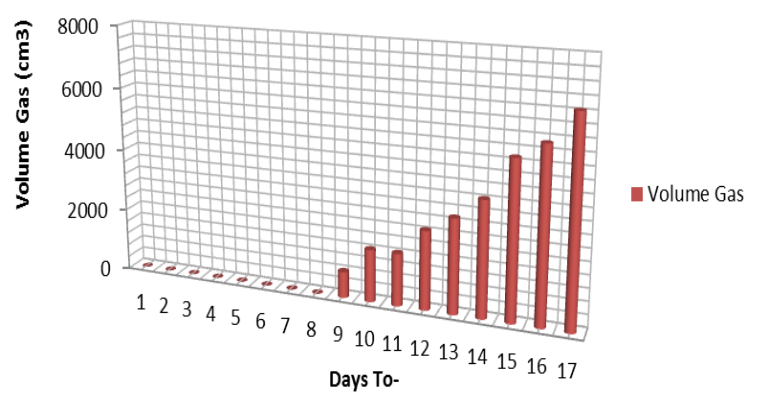

Fig. 1. Graphic Relation to the Establishment Time Gas Volume

From the results, the methane gas started coming out on the 14th with a pH of 6.5. It can be seen flames that already shows there is blue appearance, but still in small quantities. Then progressively increasing the amount of additional methane gas that is formed is also increasingly being seen from the blue color of the flames.

The formation of gas and flame testing would not be separated from how much heat is generated from the gas. Where the calorific value is only visible when the produced gas is methane gas (in $\mathrm{CO} 2$ gas is not obtained calorific values). Testing calorific value is done by connecting the device biodigester with a stove and used 
to heat $100 \mathrm{ml}$ of water and observed when a temperature change in the water. Observations on the calorific value of this

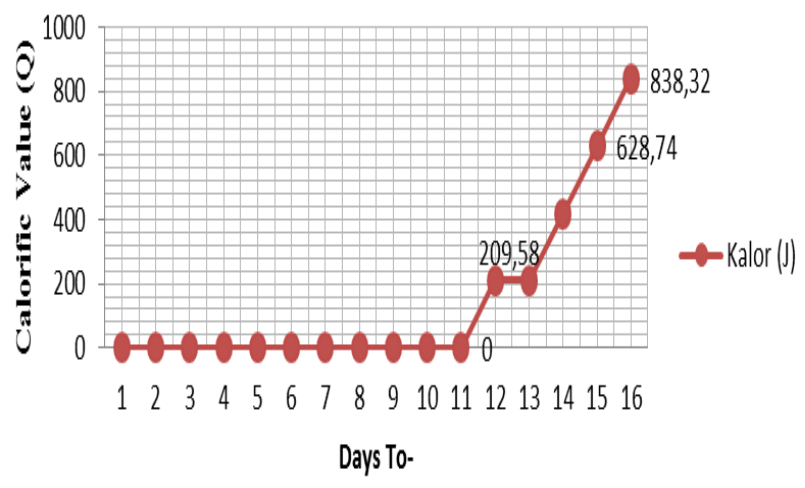

Fig.2. Relationship with Calorific Value of Time Trial Results

In figure 2 it can be seen that the calorific value obtained on the 12th day. From Table 1 it can be seen that the methane gas produced at day 14 seen from the flames. But the composition of the biogas in a small percentage have not been able to give a calorific value in the test has been done. Then on the 12th day 209.58 Joule calorific values obtained by calculation using the formula $\mathrm{Q}=$ m.c. $\Delta \mathrm{T}$ and continued to rise in the following days. Until the 17 th day of the calorific value generated at 1047.9 Joule. Broadly speaking, it can be concluded that the value of the heat produced will be greater and greater as the amount of methane produced.

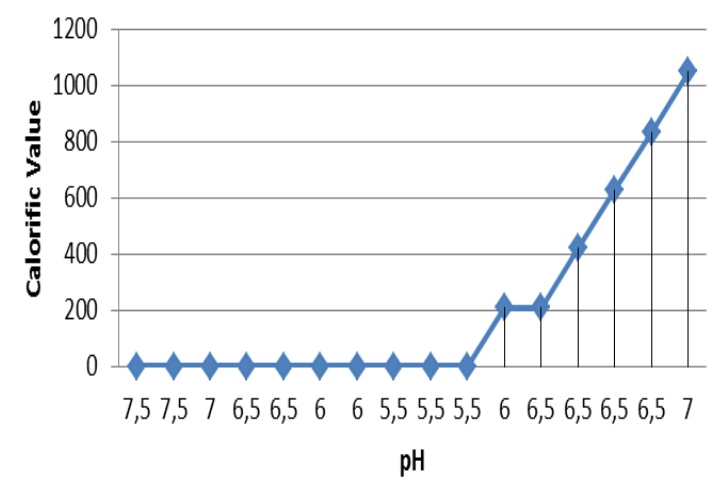

Fig.3. Relationship Graphic Calorific Values of $\mathrm{pH}$

In figure 3 the most visible $\mathrm{pH}$ optimum in the formation calorific value that is at $\mathrm{pH} 7$ wherein the calorific value generated at 1047.9 with the color blue flames and a time for 40 seconds. This is caused by anaerobic bacteria require optimal $\mathrm{pH}$ between 6.2 to 7.6 , but the good thing is from 6.6 to $7.5[6,7]$. Proven by controlling $\mathrm{pH} 7$ can generate the calorific value enough time biogas formation 17 days. The outline of the larger formation of the calorific value should be neutral $\mathrm{pH}$ conditions. $[6,8,9,10]$

\section{Conclusions}

In making biogas from waste carried out using a batchtype fixed dome biogas reactor can be concluded as follows: gas begins to form on day 9 with flame orange color yellow (not a methane gas). The methane gas begins to form on day 14 , the color of a blue flame. The heating value of methane gas is as much as 419.16 joules. Even with the addition of EM4, formation of biogas with 17 days yet to obtain maximum results. Temperatures in the digester is not optimum because the range between $270 \mathrm{C}$ to $290 \mathrm{C}$. Fixed dome biogas production with biogas reactor is very effective because the optimum gas volume increases.

\section{Acknowledgements}

Our gratitude is dedicated to Diponegoro University supporting financial for this research.

\section{References}

1. Ditjen Migas. Statistik Minyak Bumi. 2010 Available www.esdm.go.id/batubara/doc.../1256-statistikminyak-bumi-2012.html diakses 21/06/14

2. De M. Methanogenic archaeon as biogas producer in psychrophilic conditions, 76:190-5, (2014)

3. MA. Usman, OO. Olanipekun, OM. Kareem, International Journal of Research in Chemistry and Environment Biogas Generation from Domestic Solid Wastes in Mesophilic Anaerobic Digestion. 2012;2(1)

4. P. Laopaiboon, A. Thani, V. Leelavatcharamas, L. Laopaiboon, Bioresource Technology Acid hydrolysis of sugarcane bagasse for lactic acid production. (2009)

5. M. De, Optimizing low-temperature biogas production from biomass by anaerobic digestion. 2014;69

6. MM. Kabir, C, Niklasson, MJ. Taherzadeh, I. Sárvári, Bioresour Technol.; 2014;161:446-50.

7. W. Li, L. Zheng, Y. Wang, J. Zhang, Z. Yu, Y. Zhang, et al. Bioresour Technol 2015 Jun [cited 2015 Jul 16];194:276-82.

8. S. Cheng, Z. Li, H. Mang, E. Huba, Renew Sustain Energy Rev Elsevier; 2014;34:387-400.

9. E. Nutiu, Procedia Technol. Elsevier B.V.; 2014;12:632-6.

10. IM. Alfa, SO. Dahunsi, OT. Iorhemen, CC. Okafor, SA. Ajayi,. Bioresour Technol. Elsevier Ltd; 2014;157:270-7. 